\title{
プリンテッドエレクトロニクス用レーザ焼結技術： 銀ナノ粒子ペーストを用いた微細配線および機能性膜形成
}

前川 克廣*, 山崎 和彦*, 新関 智丈*, 御田 護**, 松葉 賴重 $* * *$,

寺田 信人***, 齊藤 宽***

Laser Sintering Technology for Printed Electronics:

Minute Wiring and Functional Coating with Ag-Nanoparticle Paste

Katsuhiro MAEKAWA*, Kazuhiko YAMASAKI*, Tomotake NIIZEKI*, Mamoru MITA**, Yorishige MATSUBA***,

Nobuto TERADA***, and Hiroshi SAITO***

$*$ 茨城大学工学部機械工学科（干 316-8511 茨城県日立市中成沢町 4-12-1）

**M\&M 研究所（广316-8511 茨城県日立市中成沢町 4-12-1）

***ハリマ化成株式会社筑波研究所（テ300-2635 茨城県つくば市東光台5-9-3）

* Department of Mechanical Engineering, Ibaraki University (4-12-1 Nakanarusawa-cho, Hitachi-shi, Ibaraki 316-8511)

**M\&M Laboratory, Co., Ltd. (4-12-1 Nakanarusawa-cho, Hitachi-shi, Ibaraki 316-8511)

***Tsukuba Research Laboratory, Harima Chemicals, Inc. (5-9-3 Tokodai, Tsukuba-shi, Ibaraki 300-2635)

概要 微細配線やワイヤボンディング用パッド形成に適用可能な，金属ナノ粒子ペーストのレーザ焼結に関する研究開発を進 めた。平均粒径 $5 \mathrm{~nm}$ の銀ナノ粒子ペーストを用い, バルク構造に近い機能性膜を得るためには, レーザ焼結前に溶媒除去を目的 とした加熱処理が必要であること, ペーストに対して吸光度の低い連続波近赤外レーザ光を照射して基板側から焼結させること, 高分子保護膜を離脱させるための加熱時酸素を必要としないこと，などを明らかにした。銅基板やポリイミド基板上への微細配 線形成では, $90^{\circ}-0.5 \mathrm{R}$ 曲げ㞍しピール試験に耐える基板との高い密着強度か得られ，また，約 $4.8 \mu \Omega \cdot \mathrm{cm} の$ 比抵抗值を示す導電膜 が形成された。銅基板や銅リードフレーム上へのワイヤボンディング用パッド形成に関しては，マルチステップ印刷法の採用に より, 膜厚 $2 \sim 3 \mu \mathrm{m}$ の焼結膜形成が可能となった。ボンディング後の金ワイヤのプル強度もめっき膜と同等であることを確認し た。

\begin{abstract}
An attempt has been made to develop laser sintering incorporated with ink-jet printing of metal nanoparticles. To attain a bulk-like functional-film structure with a Ag-nanoparticle ( $5 \mathrm{~nm}$ in average diameter) paste, we have clarified that preheating is necessary to reduce solvents in the paste before laser sintering, that sintering is to be started from the substrate using a continuous-wave, near-infrared laser beam with low-absorbance of the paste, and that atmospheric sintering without oxygen or argon atmosphere enables the nanoparticles to separate from the organic dispersant. Regarding minute wiring on a polyimide substrate, a high interface-adhesion induced by molecular-level mechanicallocking as well as a low specific resistance of $4.8 \mu \Omega \cdot \mathrm{cm}$ were obtained. In terms of wire-bond-pad formation on a $\mathrm{Cu}$ leadframe, a multistep printing process made it possible to form a $2-3 \mu \mathrm{m}$ thick, $\phi 100 \mu \mathrm{m}$ flat pad near the lead apex. Pull tests reveal that the wire bondability of the laser-sintered $\mathrm{Ag}$ pads is as good as that of electroplated ones.
\end{abstract}

Key Words: Metal Nanoparticles, Ink-Jet Printing, Laser Sintering, Polyimide, Leadframe, Minute Wiring, Wire-Bonding Pad

\section{1. 緒 言}

近年，急速な発展を続ける携帯電話などの小型電子機器 には，さらなる高機能化や軽量化が求められ，その内部に ある導電回路を形成したプリント配線板の微細化や製造工 程の発展, 電子モジュール実装数のさらなる増加が必要と なっている。

このような微細配線や電子モジュール実装には，局所的 に金属膜を形成する技術が欠かせない。例えば微細配線に おいては, 絶縁基板上に幅 $30 \sim 40 \mu \mathrm{m}$, 厚さ $7 \mu \mathrm{m}$ 程度の 金属の微細パターンを形成する。一方の電子モジュールの 実装では，銅製のリードフレーム $(\mathrm{LF})$ の先端に，機能性 膜と呼ばれるワイヤボンディング (WB) 用パッドを形成
し，半導体チップと，リード上のパッドを金線などで接合 する。このWB用パッドは，チップとの接合の長期信頼性 を実現するために必要となる。

絶縁基板や LF上に，局所的に金属膜を形成するために はフォトリソグラフィ法や電気めっき法が用いられてい る。フォトリソグラフィ法による微細配線形成には, 絶縁 基板の洗浄, 銅䇴のラミネート, 感光性レジストの塗布, 配線パターンの露光および現像, 銅䇴のケミカルエッチン

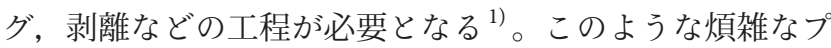
ロセスに加え，材料の使用効率の低さやエッチング後の廃 液処理なども課題となる。

めっき作業においても, 素地の油脂, アルカリ, 酸化 膜，さび，ごみなどを除去するための前処理（研磨，溶剤 
脱脂, 酸処理, 水洗), めっき浴の管理, 後処理（水洗, 乾燥), 廃液処理などの関連工程が必要である。これらの 工程では, 大量の化学薬品と液体を必要とし，これらす心゙ てを回収して無害化しなければ工場外に排出することがで きない。

また，フォトリソグラフィ法や電気めっき法におけるプ ロセスの複雑さは, 製造コストの削減において大きな障壁 にもなり，環境負荷が大きい点も，近年の省エネルギ・省 資源の観点から問題である。そのため，局所的な金属膜を 形成する技術や製造プロセスに打年省資源化や低環境負 荷化が要求されている。

一方，微細配線や機能性膜形成技術として，金属ナノ粒 子ペーストのインクジェット (IJ) 印刷技術，およびその 金属化プロセスからなるドライプロセスが注目を集めてい る2)。IJ印刷技術では，少量の金属ナノ粒子ペーストを， 所要部位にのみ供給できることから, 微細配線パターンや 局所的な機能性膜形成が可能となる。そのため, 金属材料 の使用効率が良く, 省資源・低環境負荷で, 低コス卜化の 面においても期待されている。

金属ナノ粒子ペーストの金属化プロセスとしては，これ まで，電気炉などを用いて $220 \sim 250^{\circ} \mathrm{C}$ 付近で加熱を行う 炉焼成法が用いられてきた。しかし近年では，このような 熱処理工程で発生した熱ダメージが，膜と基板との密着強 度の低下の原因となるため, 局所加熱で基板への熱ダメー ジが少ない金属ナノ粒子のレーザ焼結法に関する研究が盛 んとなっている ${ }^{3) \sim 5) 。 ~}$

Fig. 1 に，金属ナノ粒子のIJ印刷ならびにそのレーザ焼 結法を用いた，微細配線および機能性膜形成技術の概念を 示す。ポリイミド (PI) 基板や LF 上の, 任意の部位に塗布 した金属ナノ粒子ペーストにレーザ照射を行い，局所的に 加熱，焼結させることで金属膜を形成する。このように， 本手法ではパターン印刷のためのマスクが必要なく，また 大気中で行うドライプロセスであるため, フォトリソグラ フィ法のような基板の前処理工程や廃液処理を必要としな い。

また，必要な部位にのみペーストを塗布できるため，導 電材料の利用効率も高く, 炉焼成法と違って一瞬で膜形成 プロセスが完了する。このことから本技術は，省資源・低 環境負荷型の「高速レーザめっき法」といえる。

本研究では, 金属ナノ粒子ペーストのIJ印刷技術とレー ザ焼結技術を組み合わせ，省エネルギでインライン化が可 能な, 微細配線やWB 用パッド形成を可能とするドライプ ロセスの開発を目的とする。とくに，金属ナノ粒子ペース トのレーザ焼結に着目し，そのメカニズムを明らかにす る。

ここでは，微細配線技術の確立に向け，銅やPI基板上 に微細配線を形成し，得られた膜の組織，銀焼結膜と基板 との密着性，銀線の導電性に及ぼすレーザ波長の影響につ
Ink head

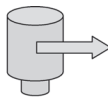

Ag paste droplet

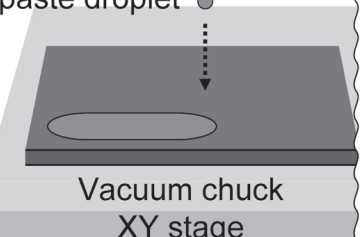

Polyimide substrate

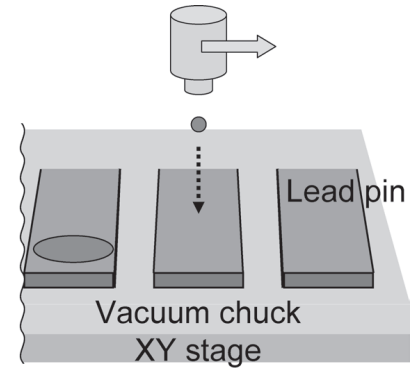

Cu leadframe

\section{(a) Ink-jet printing}

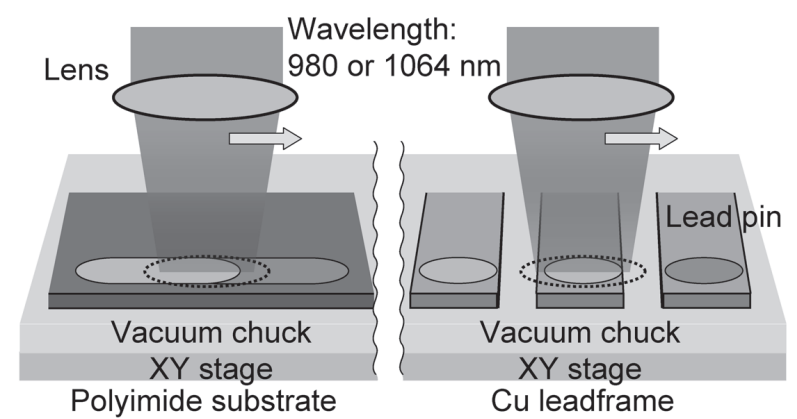

(b) Laser sintering

Fig. 1 Schematic of minute wiring and functional coating by (a) ink-jet printing and (b) laser sintering using metal nanoparticles

いて検討した。また，リード先端に形成したWB用パッド の組織観察のほか, WB後のワイヤのプル強度試験を行う ことで膜と基板との密着性を評価し，本技術の実用化に向 けた検証を行った。

\section{2. 金属ナノ粒子のインクジェット印刷とレーザ焼結}

今回は，平均粒径 $5 \mathrm{~nm}$ の銀ナノ粒子ペースト（ハリマ 化成, NPS-J-HTBもしくはNPS-J) を，スピンコート法, もしくはあらかじめ決められたパターンで基板上に IJ印刷 し，レーザ照射を行うことで配線パターンや機能性膜を形 成した。

Fig. 2 は, 銀ナノ粒子ペーストの透過型電子顕微鏡 (TEM) 像である。分散した銀ナノ粒子が観察されてい る。また，Fig. 3 に，20,000倍に希釈した銀ナノ粒子ペー ストの吸収スペクトルを示す。このペーストは，波長 $600 \mathrm{~nm}$ から短波長側に吸収があり, 波長 $420 \mathrm{~nm}$ 付近にお いて吸収のピークが見られる。一方，近赤外波長領域にお いては吸収が少ない。

この銀ナノ粒子ペーストを，基板上に塗布し，ホットプ レートによる仮乾燥（銅基板用には温度 $170^{\circ} \mathrm{C}$ ，保持時間 $20 \mathrm{~min}$, PI 基板用には $100^{\circ} \mathrm{C}, 1 \mathrm{~min}$ ）を行った。仮乾燥は ペースト中の溶媒の除去が目的であり，これを行わなけれ ばレーザ照射時の溶媒の気化に伴い，ナノ粒子が飛散して 


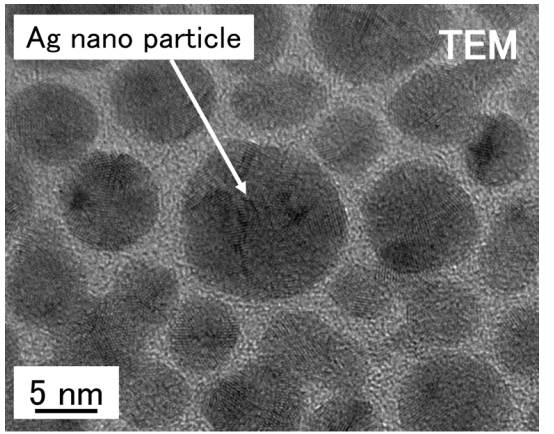

Fig. 2 TEM image of Ag-nanoparticle paste

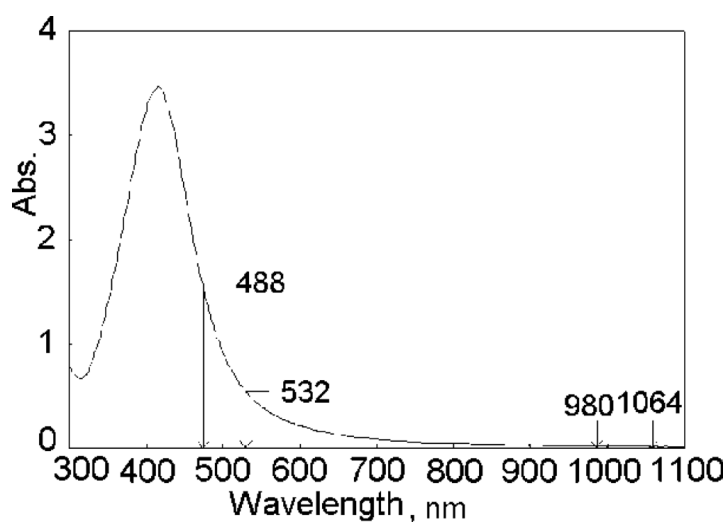

Fig. 3 Absorbance spectrum of Ag-nanoparticle paste

しまう。その後, Nd:YAGレーザ（波長 $1,064 \mathrm{~nm}$, 連続発 振または繰り返し周波数 $1 \mathrm{kHz}$, ビームスポット径約 $0.4 \mathrm{~mm}$ ）や，半導体レーザ（波長 $980 \mathrm{~nm}$ ）, Arイオンレー ザ（波長 $488 \mathrm{~nm}$ ）を，目的に応じてビーム走査速度 0.5 $18.9 \mathrm{~mm} / \mathrm{s}$ で集光照射し，焼結膜を形成した。

Fig. 4 に用いたIJ印刷装置を示す。IJ印刷装置は印刷 ヘッド，XYステージ，インクタンク，コントローラなど で構成されている。印刷ヘッドは128個のマイクロノズル をもち, インク吐出量は $11 \mathrm{pl}$, 解像度は $1,200 \mathrm{dpi}$ である。 同図 (b) はへッドから吐出された直後の液滴の様子を示 す。糸を引いた液滴は，ある一定の距離を助走した後球形 になる。

Fig. 5 は，Nd:YAGレーザ焼結装置である。発振部は LASER SOS社製SOS8956QSSであり，f $\theta$ レンズを介して集 光されたレーザ光は，XY ステージ上の基板に照射される。 同図 (b) は，レーザ照射部を示す。基板には，金属ナノ粒 子ペーストが必要な䇢所のみに塗布されており,これをス テンレス鋼製ジグで固定し, ジグの内側に $31 / \mathrm{min}$ の $\mathrm{Ar}$ ガ スを流した。Arガスは，基板の酸化防止と冷却，焼結時 の排出ガス除去を目的に使用した。酸素濃度計による測定 では,このときの酸素分率はゼロであった。

\section{3. 基板上への微細配線形成}

\section{1 銅基板上への微細配線形成 ${ }^{6)}$}

基板上への微細配線形成のための基礎研究として，まず

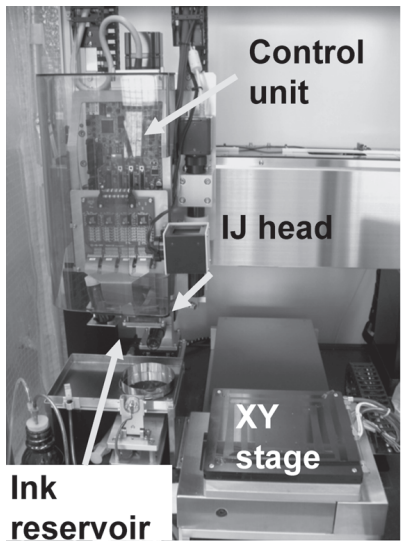

(a) IJ printer

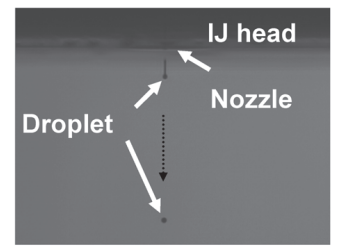

(b) Discharge appearance
Fig. 4 Ink-jet printing apparatus

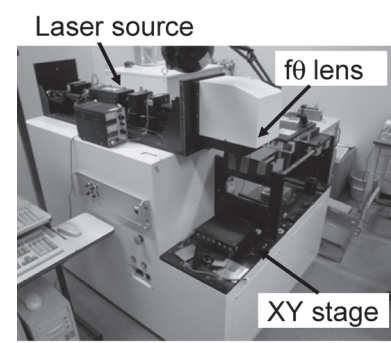

(a) Nd: YAG laser

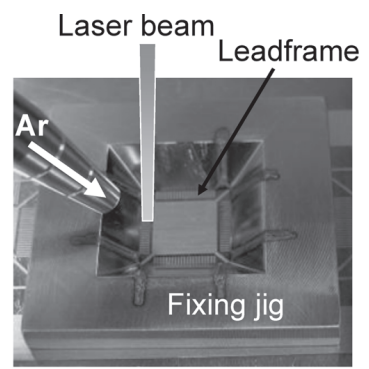

(b) Irradiation position
Fig. 5 Laser sintering apparatus

銅基板（JIS C1220P材，板厚 $1 \mathrm{~mm}$ ）上に，銀ナノ粒子 ペーストの配線パターンをIJ印刷により形成し，仮乾燥 （温度 $170^{\circ} \mathrm{C} ， 20 \mathrm{~min}$ ）を行った。このときの配線幅は約 $70 \mu \mathrm{m}$, 平均膜厚は約 $2 \mu \mathrm{m}$ であった。その後, 大気雾囲気 下でNd:YAGレーザ（連続発振, 出力 $90 \mathrm{~W}$, もしくはパ ルス発振, 出力 $0.2 \sim 15 \mathrm{~mJ} /$ pulse, 繰り返し周波数 $1 \mathrm{kHz}$ ) を集光照射した。このときのレーザの走查速度は $18.9 \mathrm{~mm} / \mathrm{s}$ とした。

Fig. 6 (a) および (b) に，パルスレーザ照射前後の配線 サンプルの光学顕微鏡像を示す。同図 (b) 上り, 照射エ ネルギが増すと焼結部位基板が透けて見えるようになる。 このことは，焼結時により多くの銀粒子が飛散したことを 意味する。なお，連続発振レーザによる照射では，仮乾燥 後膜厚が $2 \mu \mathrm{m}$ を超える場合には，塗布したペースト内部 まで完全に焼結しない場合がある。未焼結部位が残ること は，別報无により確認されている。

Fig. 6 (c) に, レーザ照射後の走査型電子顕微鏡 (SEM) 像を示す。SEM像から，銀配線がレーザ照射により形成 された銀焼結粒の集合体であることが確認された。焼結粒 のサイズは, 照射エネルギの増加に伴って $0.4 〜 1.0 \mu \mathrm{m}$ へ 増大している。またエネルギ分散型X線 (EDX) 分析の結 果（Fig. 7参照）から，焼結粒中心付近 Bでは約 $51 \mathrm{wt} \%$ の 


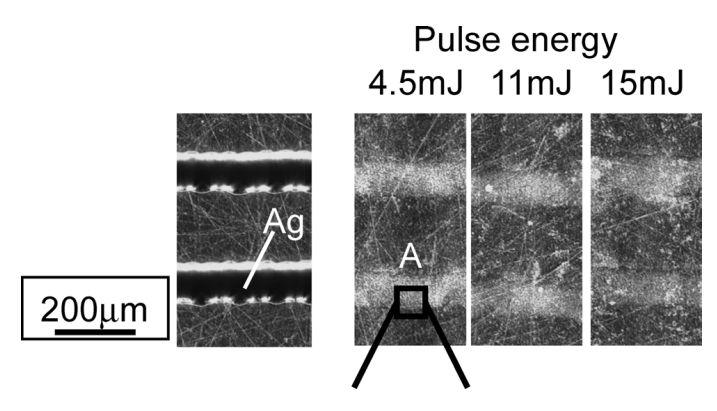

(a)

(b)

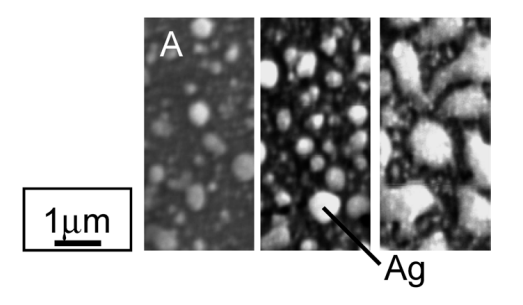

(c)

Fig. 6 Ag wiring before/after laser sintering: (a) optical micrograph before sintering, (b) optical micrograph after sintering, (c) SEM image after sintering

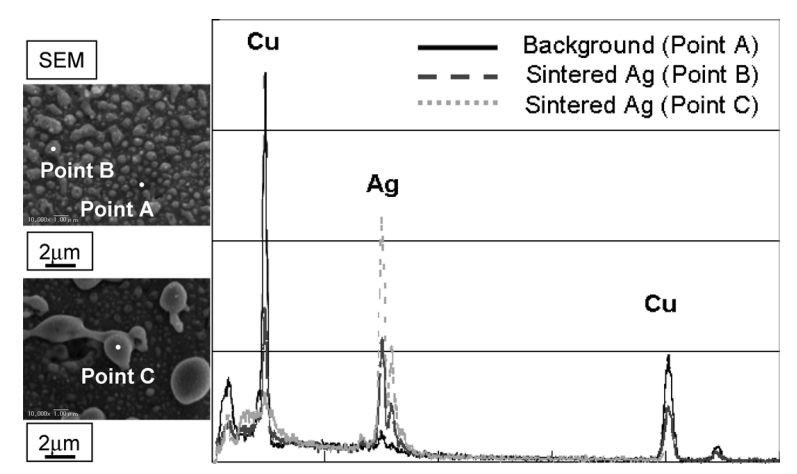

Fig. 7 Result of energy dispersive X-ray spectrometry (EDX) analysis of sintered Ag particles: irradiated pulse energy, about $11 \mathrm{~mJ}$

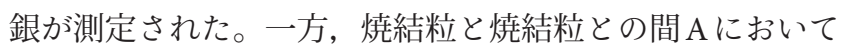
も約 $7.4 \mathrm{wt} \%$ の銀が確認された。SEM-EDXのプローブ径は $28.6 \mathrm{~nm}$ であり, 粒間距離も $200 \mathrm{~nm}$ 以上であることから, 銀焼結膜は，焼結範囲全体に形成していると推測される。

次に形成した銀の配線サンプルの $90^{\circ}-0.5 \mathrm{R}$ 曲げ戻しピー ル試験を行い，基板との密着性について評価した。この試 験法は，0.5Rの丸みをもつ圧子を基板に押し付けて $90^{\circ}$ 曲 げた後, 水平に曲げ戻し, その後粘着テープによる剥離の 有無を調べるものである。Fig. 8 に曲げ戻しピール試験後 のサンプルの様子を示す。低出力の場合には銀配線にわず かの剥離が観察されるが, 高出力の場合は剥離がまったく 確認されない。なお, 照射したパルス数は, 前述の $\mathrm{Nd}$ : YAGレーザの照射条件（繰り返し周波数 $1 \mathrm{kHz}$ ，ビー ムスポット径約 $0.4 \mathrm{~mm}$, ビーム走査速度 $18.9 \mathrm{~mm} / \mathrm{s}$ ) では 線幅 $70 \mu \mathrm{m}$ 当たり, 21 パルス前後である。

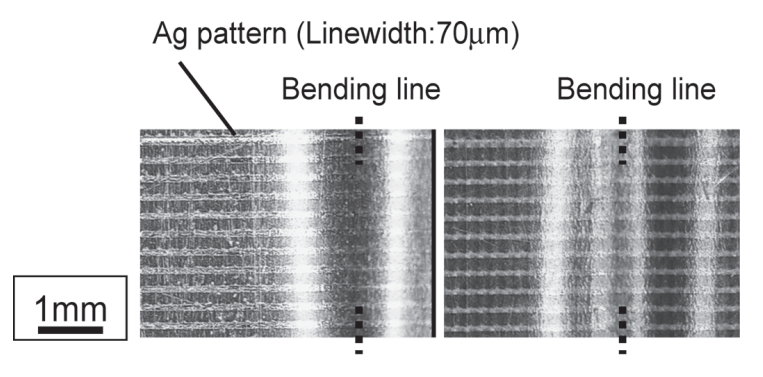

(a) $0.2 \mathrm{~mJ} /$ pulse

(b) $4.5 \mathrm{~mJ} /$ pulse

Fig. 8 Optical micrographs after bend-peel test
(1) Spin coating

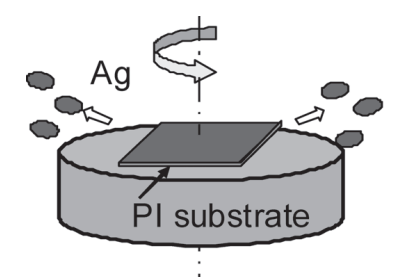

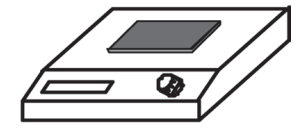

(2) Drying

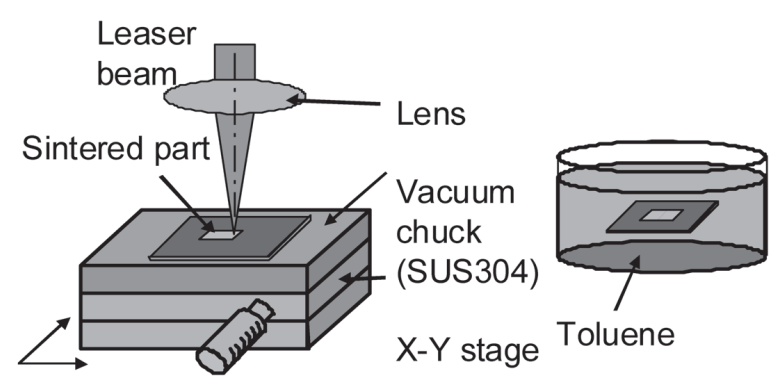

(3) Laser sintering

(4) Cleansing

Fig. 9 Wiring procedures on polyimide substrate

\section{2 ポリイミド基板上への微細配線形成 ${ }^{7)}$}

次にPI基板上への微細配線形成を試みた。PI基板（東 レ・デュポン, カプトン $500 \mathrm{H}$, 板厚 $0.125 \mathrm{~mm}$ ）上に, 膜 厚制御に優れるスピンコート法を用いて銀ナノ粒子ペース 卜を塗布した。PI基板では，基板表面の撥水作用の制御 が困難で，高精度な配線パターンの印刷や膜厚制御が銅基 板よりも難しいの。

Fig. 9 に配線形成方法を示す。異なる回転数 1,000 , 2,000，4,000 rpmで銀ナノ粒子ペーストをスピンコート し, 仮乾燥（温度 $100^{\circ} \mathrm{C}, 1 \mathrm{~min}$ ）を行った。その後, 大気 中雾囲気下において連続発振の半導体レーザ（波長 $980 \mathrm{~nm}$ ）または $\mathrm{Ar}$ イオンレーザ（波長 $488 \mathrm{~nm}$ ）を集光照 射した。レーザの走査速度はレーザ波長にかかわらず一定 とし， $4 \mathrm{~mm} / \mathrm{s}$ とした。レーザ照射後，トルエンによる洗 浄を行い，未焼結部分の銀ナノ粒子を除去した。

PI基板上に形成した銀配線について，銅基板上に作製し たサンプル同様，90-0.5R曲げ戻しピール試験を行い，銀 焼結膜と基板との密着性を評価した。Fig. 10 (a) に, 半導 体レーザ照射によって得られた銀配線の様子を, Fig. 10 (b) 
Bending line

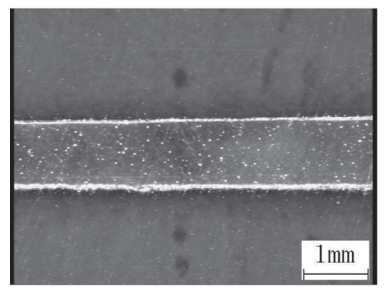

(a) Before

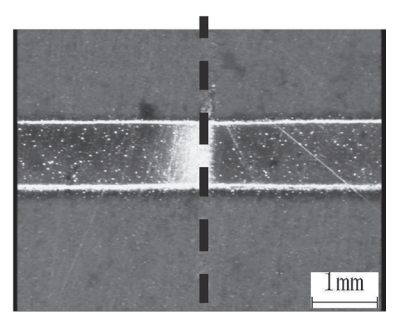

(b) After
Fig. 10 Ag wiring on polyimide substrate before/after bend-peel test: spin-coater speed, 1,000 rpm; laser diode output, $5.3 \mathrm{~W}$; scanning speed, $4 \mathrm{~mm} / \mathrm{s}$

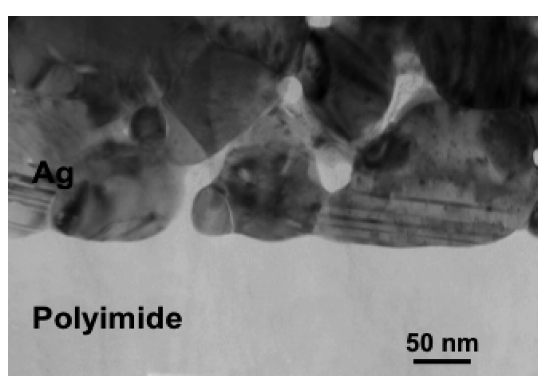

Fig. 11 Cross-sectional TEM images of $\mathrm{Ag} /$ polyimide interface

に，その配線の曲げ戻しピール試験後の様子を示す。その 結果, 焼結膜と PI界面で剥離は生じず, 基板との高い密着 性が得られている。一方, Arイオンレーザ照射で得られた 配線サンプルにおいても, 基板との剥離は生じず高い密着 性が確認されている7)。

このような高い密着性が得られる理由は，PI基板と焼 結された銀との界面の構造にあると考えられる。Fig. 11 は, Ag/PI界面の TEM像である。銀ナノ粒子ペーストにほ とんど吸収されずにPI表面に到達したレーザ光がPI表面 を溶融する。この溶融層に有機分子保護膜の取れた銀ナノ 粒子が入り込み，その状態で焼結が進んでいく。その結 果，PI表面の山凸に銀原子が入り込んだ状態が観察され ている。すなわち, 機械的アンカー効果が密着力を高めて いるものと考えられる。

Fig. 12 に，レーザ出力と銀焼結膜の比抵抗值の関係を示 す。ここで, 得られた膜厚は, 回転数 $1,000,2,000$, $4,000 \mathrm{rpm}$ の条件で, それぞれ約 0.50 , 約 0.20 , 約 $0.15 \mu \mathrm{m}$ である。すべての回転数条件において, レーザ出力が高く なると, 配線の比抵抗值が小さくなる傾向にある。これ は，照射するレーザ出力の増加によって膜内部まで焼結が 進行するが, 出力が十分に高いと内部に未焼結部位が存在 しないためと推測される。なお, 図中のレーザ出力の最高 值はPI基板の耐熱限界である。結果として, 半導体レー ザの照射によって得られた銀配線の最小の比抵抗值は約 $4.8 \mu \Omega \cdot \mathrm{cm}$ である。これは金属ナノ粒子ペーストの炉焼

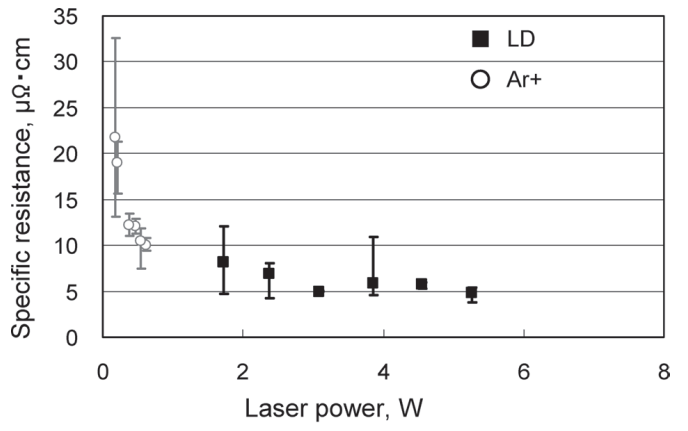

(a) $1000 \mathrm{rpm}$

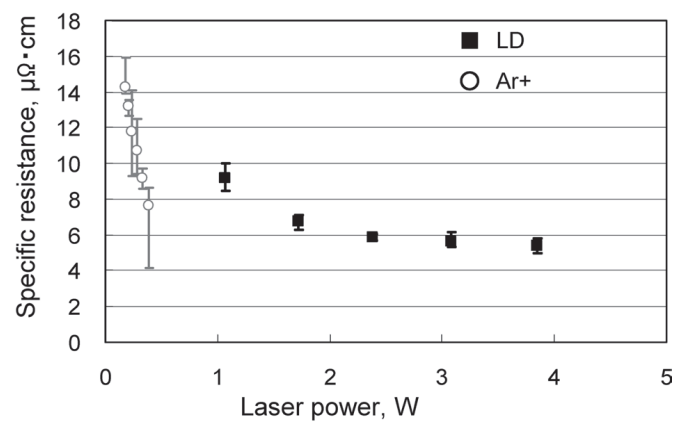

(b) $2000 \mathrm{rpm}$

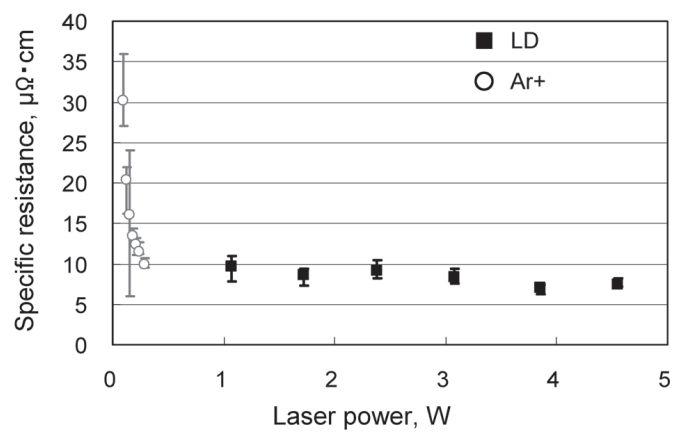

(c) $4000 \mathrm{rpm}$

Fig. 12 Specific resistance of Ag wires vs. laser power as a function of spin-coater rotation speed, depending on laser sources and spin-coater speed with scanning speed $4 \mathrm{~mm} / \mathrm{s}$

成によって得られたバルク銀の比抵抗の約 1.5 倍である。 一方, Arイオンレーザの場合, 最小の比抵抗值は約 $8 \mu \Omega \cdot \mathrm{cm}$ となっている。

Fig. 13 にレーザ焼結膜の集束イオンビーム (FIB) 加工後 の断面の走査イオン顕微鏡 (SIM) 像を示す。ここで,

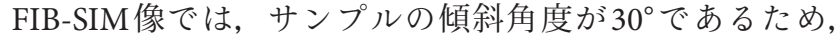
縦方向の実距離は横方向のスケールの2倍となる。Fig. 13 (a) は半導体レーザ，同 (b) はArイオンレーザ照射に よって得られた銀焼結膜であるが，いずれの焼結膜もやや 多孔質構造である。また波長のより長い半導体レーザの方 が，比較的緻密な焼結膜が得られている。なお，Fig. 12 に おいて薄い膜厚の比抵抗值が大きいのは，多孔質構造の影 


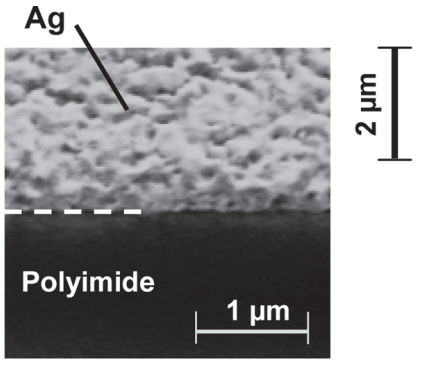

(a) Laser diode (1000 rpm, $5.3 \mathrm{~W}$ )

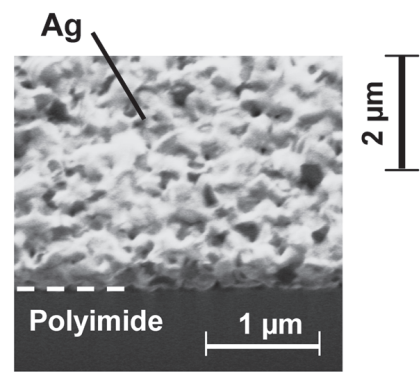

(b) Ar ion laser (1000 rpm, $1.3 \mathrm{~W}$ )

Fig. 13 FIBed cross-sectional SIM images of Ag film sintered on polyimide substrate (scanning speed $4 \mathrm{~mm} / \mathrm{s}$, tilted by $30^{\circ}$ )

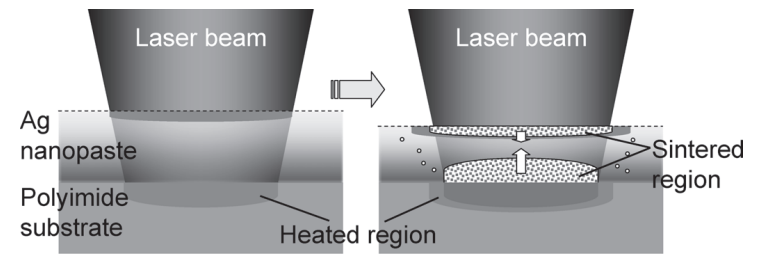

(a) Low-absorbance laser diode

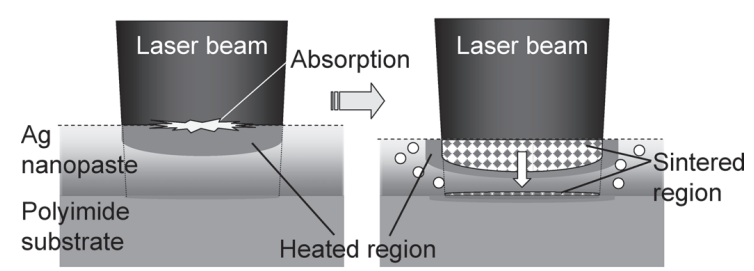

(b) High-absorbance Ar ion laser

Fig. 14 Influence of laser wavelength on sintering mechanism of Ag-nanoparticle paste

響と考えられる。

この原因は, 焼結メカニズムの違いによるものと推測さ れる。Fig. 14 に焼結メカニズムの模式図を示す。前述の Fig. 3 に示すように, 半導体レーザ光（波長 $980 \mathrm{~nm}$ ）は, 銀ナノ粒子ペーストであまり吸収されず，ペースト中を透 過してPI基板に吸収および加熱される（Fig. 14 (a) 参照)。 これにより，基板側からの熱伝導によって銀ナノ粒子の焼 結が進む。

これに対し，Arイオンレーザの波長域（波長 $488 \mathrm{~nm}$ ）

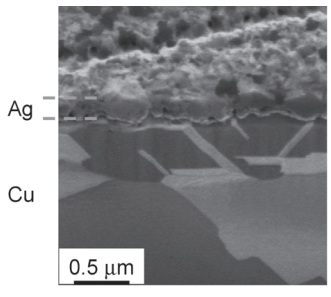

(a) $2000 \mathrm{rpm}$

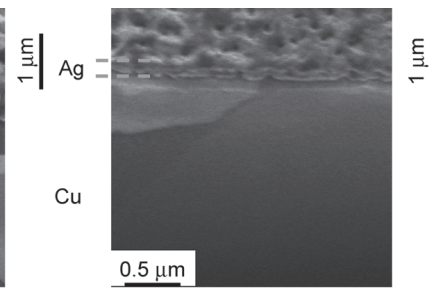

(b) $4000 \mathrm{rpm}$

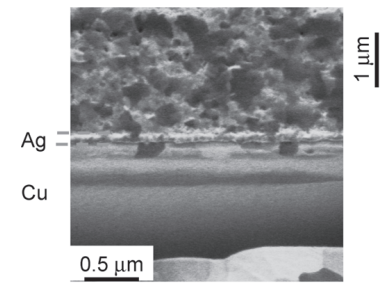

Fig. 15 FIBed cross-sectional SIM images of Ag film sintered on Cu substrate (tilted by $30^{\circ}$ ) as a function of spin-coater rotation speed

においては，ペーストに強い吸収があり，ほとんどの光が 銀ナノ粒子ペースト表面で吸収され，ペーストの表面側か ら焼結が進む（Fig. 14 (b) 参照）。その結果, ペースト中 の溶媒が逃げ場を失って内部圧力が高まり，気化したガス が放出する過程で比較的大きな空洞が形成される。これに より，比抵抗值が増加したものと推測される。

以上のことから，銅基板やPI基板上への微細配線形成 では，基板との高い密着強度を示す導電膜の形成が可能で ある。しかしながら，微細配線への応用を考えると，バル クの膜質に近い，少なくとも膜厚 $7 \mu \mathrm{m}$ を超える焼結膜を 得るための焼結プロセスの確立が課題である。

\section{4. 銅リードフレーム上の機能性膜形成}

\section{1 銅基板上への機能性膜形成 ${ }^{6), 8}$}

機能性膜形成に向けた基礎研究として，銅基板上への機 能性膜形成を試みた。アルカリ溶液による脱脂およびリン スを行った銅基板（JIS C1220P材，板厚 $0.3 \mathrm{mm）上に,}$ 異なる回転数 2,000，4,000，6,000 rpm で銀ナノ粒子ペース トをスピンコートし，その後，大気中雾囲気下において連 続発振の Nd:YAGレーザ（波長 $1,064 \mathrm{~nm}$, 出力 $130 \mathrm{~W}$ ）を 照射した。このときレーザの走査速度は $0.5 \mathrm{~mm} / \mathrm{s}$ とした。

その結果, 比較的膜厚のある回転数 $2,000 \mathrm{rpm}$ のサンプ ル表面は未焼結（青みがかった色）であり，それ以外の膜 は金属光沢を示した。Fig. 15 に，それぞれの焼結膜のFIB 加工後の断面 SIM 像を示す（傾斜角度 $30^{\circ}$, 縦方向の実距 離はスケールの2倍)。得られた焼結膜の膜厚は $0.12 〜$ $0.50 \mu \mathrm{m}$ で, 塗布時の回転数が増加するにつれ薄膜が形成 している。

次に, 得られた焼結膜の X線光電子分光 (XPS) 分析を 行った。Fig. 16はその結果の一例である。膜表面の成分の 


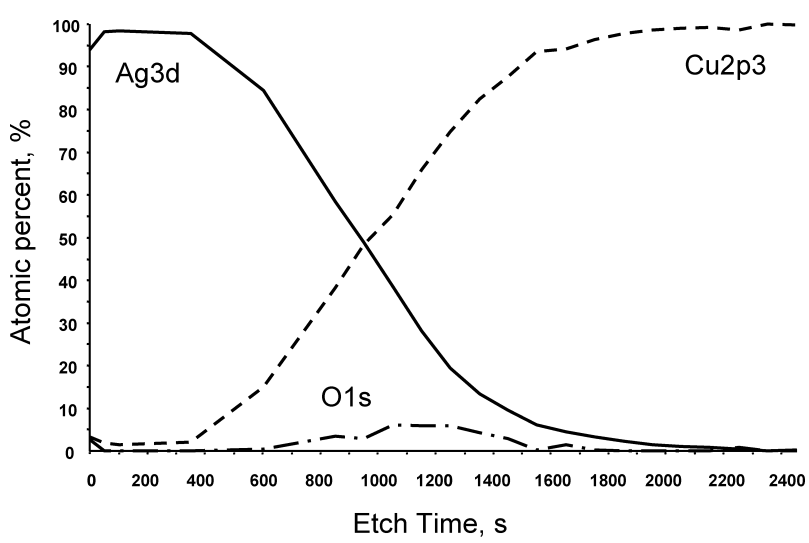

Fig. 16 Atomic percent of cross-section of sample in Fig. 15 (b)

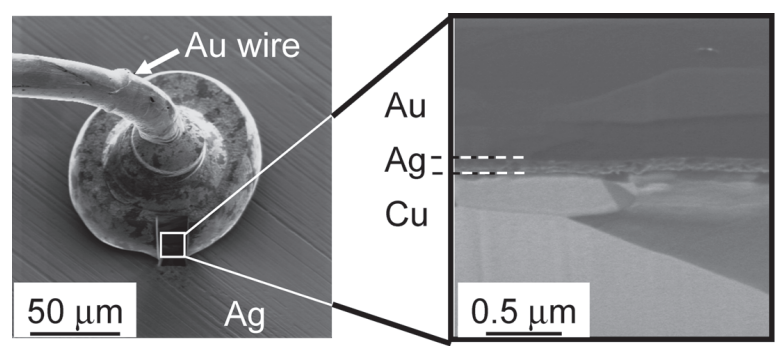

(a) Enlarged view

(b) Cross-sectional SIM image

Fig. 17 Wire bonding on Ag film sintered on Cu substrate

ほとんどが銀であり，銅基板との界面にわずかな酸化層や 拡散した銀ならびに銅の成分が確認された。レーザ焼結膜 の基板との高い密着力は，このような，界面での $\mathrm{Ag} と \mathrm{Cu}$ の相互拡散が寄与しているものと考えられる。

これらの結果から，1回のレーザ照射により得られる焼 結膜の最大厚さは約 $0.20 \mu \mathrm{m}$ となる。そこで, ペーストの 塗布とレーザ焼結を繰り返す積層膜形成法を用い，5層の 積層焼結膜形成を試みた。その結果，厚さ約 $1.0 \mu \mathrm{m}$ の焼結 膜が得られ，銀-銅間だけでなく銀-銀層間においても剥 離がないことが確認された。これにより銀焼結膜の厚膜化 においては積層法が有効であることがわかった ${ }^{8)}$ 。

次に，マニュアルワイヤボンダを用い，直径 $\phi 25 \mu \mathrm{m}$ の 金線のWBを行い，そのプル強度を評価した。Fig. 17 に, 焼結膜上にボール (1st) ボンディングを行った様子を示 す。断面SIM像から, 膜の剥離は観察されず，WBパッド として機能しているが，銅基板に存在する圧延痕に起因す る隙間が観察されている。

ボンディングした金線にフックを引っ掛け，ワイヤまた は膜が破断するまで引張り，その強度を測定した。測定し たプル強度試験を, Fig. 18に示す。サンプル数は20で, 炉焼成膜 $\left(220^{\circ} \mathrm{C}, 60 \mathrm{~min}\right)$ と比較した。その結果, すべて の焼結膜において金線のプル強度は打おむ称 $5.5 \sim 6 \mathrm{cN}$ あったが，レーザ焼結膜では，ほとんどがウェッジ (2nd) ボンディングで剥離した。また膜厚 $0.12,0.20 \mu \mathrm{m}$ の焼結 膜に対する剥離率は約 $4 \%$, 膜厚 $0.50 \mu \mathrm{m}$ のときは約 $30 \%$,
Pull strength, $\mathrm{cN}$

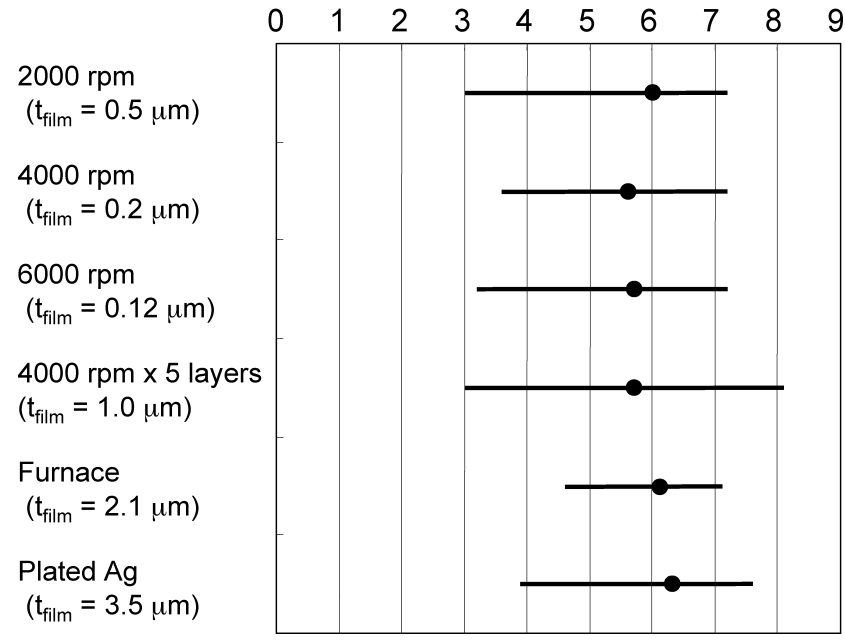

Fig. 18 Pull strength of Au wire bonded on Cu substrate with Ag film (20 samples)

前述の5 層積層膜（膜厚 $1.0 \mu \mathrm{m}$ ）の剥離率は約 $4 \%$ であっ た。炉焼成膜に比べて，レーザ焼結膜のプル強度がばらつ いている。

以上のように，焼結膜の膜厚や膜質，評価サンプル数な どさらなる改善が必要であるが，本技術で得られた銅基板 上の銀焼結膜は, WB用パッドとして有効に機能すること がわかった。

4.2 銅リードフレーム上への機能性膜形成 ${ }^{99,10)}$

\subsection{1 シングルステップ印刷}

リード先端幅 $0.3 \mathrm{~mm}$ の銅 $\mathrm{LF}$ のリード先端に，銀ナノ粒 子ペーストのIJ印刷を行った。このときの印刷パターン は，液滴量 $11 \mathrm{pl}$ の銀ナノ粒子ペーストを 1 回印刷するパ ターンとした。その後, 不活性ガス雾囲気下で, 連続発振 の Nd:YAGレーザ（波長出力 $1,064 \mathrm{~nm} ， 50 １ 30 \mathrm{~W}$ ）を集 光照射した。またレーザの走査速度は $4 \mathrm{~mm} / \mathrm{s}$ とした。

Fig. 19 に，リード先端に形成した焼結膜の様子を，また Fig. 20 にレーザ焼結膜の断面 TEM像を示す。焼結膜の形 成範囲は $\phi 250 \sim 300 \mu \mathrm{m}$ で膜厚は約 $0.20 \mu \mathrm{m}$ であった。膜 厚が薄い場合には，銀燒結膜はほぼ完全にバルク化してお り, 格子間隔 $0.2 \mathrm{~nm}$ の結晶構造も観察される。これは, $75 \mathrm{~ms}$ の短時間のレーザ照射によって，銀ナノ粒子ペース トの焼結が完了することを表している。しかしながら，焼 結後の膜厚が $0.5 \mu \mathrm{m}$ 以上と厚い場合には，多孔質膜が形成 される傾向にある。LF上の機能性膜形成技術としての実 用化に向け，長期信頼性を得るためには，少なくとも $2 \mu \mathrm{m}$ 以上の膜厚の機能性膜が必要となる。

Fig. 19には，銀の移流集積も観察される。Coffee stain 現象 ${ }^{11)}$ とも呼ばれ，溶媒中の微粒子が加熱時に熱対流に より液滴周囲に集まる現象である。液滴量を増やせば，こ の現象が助長され, 凹状の中央部をもつ焼結膜となってし まう。その結果, WBに必要な平坦なパッドを得ることが できない。 


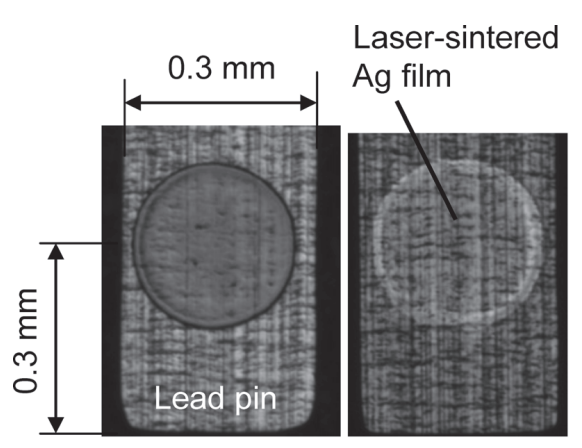

(a) IJ-printed (b) Laser-sintered

Fig. 19 Single-step IJ-printed and laser-sintered patterns on Cu leads

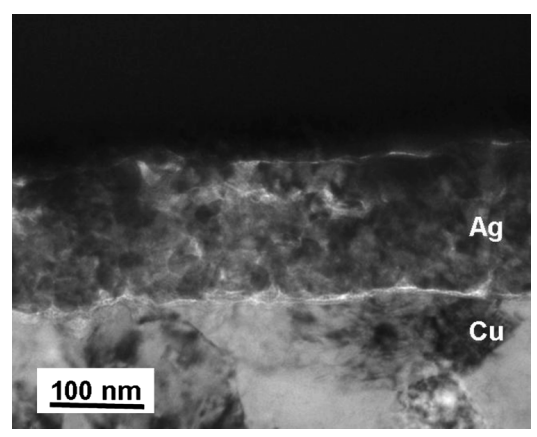

Fig. 20 Cross-sectional TEM image of laser-sintered Ag nanoparticle paste

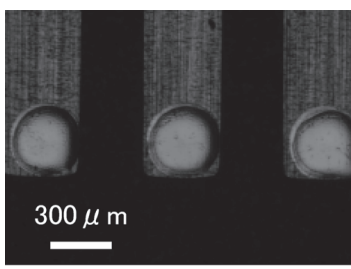

(a) Before laser sintering

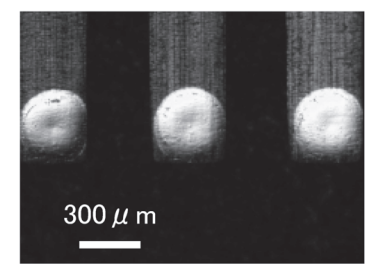

(b) After laser sintering
Fig. 21 Multi-step IJ-printed and laser-sintered patterns on Cu leads

\subsection{2 マルチステップ印刷}

単層印刷による機能性膜形成では, 膜厚約 $0.20 \mu \mathrm{m}$ が限 界であった。そこで, 機能性膜の厚膜化と平坦化に向け, 複数回に分けてペーストを塗布する積層印刷法を考案し た。液滴の移流集積現象を利用し，まず，やや大きめの第 1層をIJ印刷した後, 溶媒を除去するための乾燥工程を入 れ，周囲に土手を作る。次に，土手から溢れないように液 滴量を調節して第2層を作る。このステップを何度か繰り 返した後，印刷したパッドがあるリード先端のみにレーザ を1回だけ照射すれば，ほぼ平坦な厚い膜を得ることがで きる。

Fig. 21 に，マルチステップ印刷法を用いてリード先端に 形成した機能性膜の様子を示す。Fig. 21 (b) に示すレーザ 照射後では，膜表面に金属光沢か観察されている。Fig. 22 に, レーザ顕微鏡を用いてこの焼結膜の膜厚プロファイル

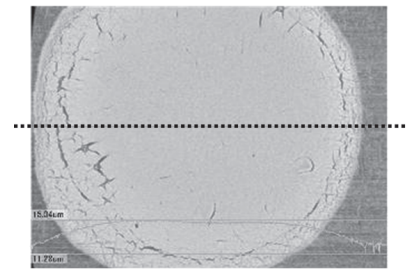

(a) Optical micrograph

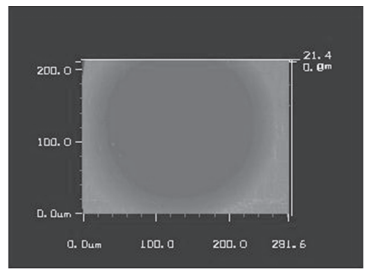

(b) Color image

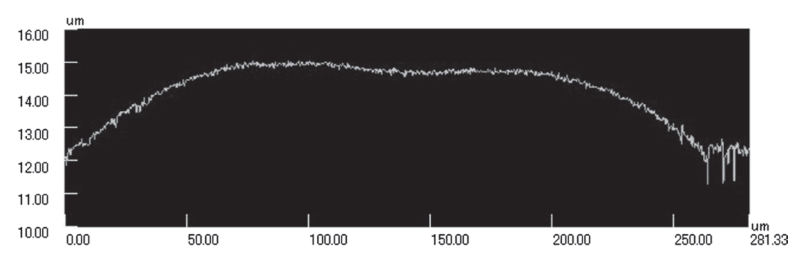

(c) Cross-sectional profile

Fig. 22 LSM images of laser-sintered Ag nanoparticle paste

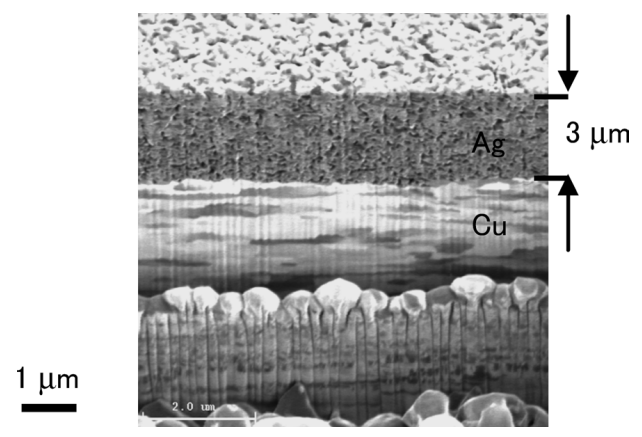

Fig. 23 FlBed cross-section of laser-sintered Ag nanoparticle paste on Cu lead (tilted by $30^{\circ}$ )

を測定した結果を示す。適したパターンと乾燥工程を用い てペーストを積層印刷することで，厚みがあり，かつ平坦 な膜の形成に成功している。

Fig. 23 に，レーザ焼結膜の FIB 加工後の断面SIM 像を示 す（傾斜角度 $\left.30^{\circ}\right)$ 。前述の単層印刷法による焼結膜の膜厚 が約 $0.20 \mu \mathrm{m}$ （Fig. 19，20参照）であったのに対し, 積層 印刷法では約 $3.0 \mu \mathrm{m}$ の膜厚が得られ，基板界面での未焼結 部位も存在しない。前述の銅基板上での基礎研究では, レーザ出力を増加しても，膜内部での未焼結部位が観察さ れていた。このような基板とリード先端における焼結特性 の差は, リード先端の三方が大気に囲まれていることによ る。すなわち，リード形状が蓄熱効果を生み，レーザのエ ネルギが効率良くナノ粒子の焼結に利用されたために生じ たのではないかと推測される。

次に, リード先端に形成した機能性膜の WB プル強度を 評価した。比較のため, 同じ銅LF上にめっき膜を形成し, それぞれ直径 $25 \mu \mathrm{m}$ の金線のWBを行った後,プル強度を 測定した。Table 1に，それぞれの機能性膜に対するプル 強度測定結果を示す。膜厚約 $0.20 \mu \mathrm{m}$ と約 $3.0 \mu \mathrm{m}$ のレーザ 焼結膜における平均プル強度は，それぞれ約 $8.2 \mathrm{cN}$, 約 $8.6 \mathrm{cN}$ と，めっき膜とほぼ同等の強度が得られている。 
Table 1. Pull strength of $\phi 25 \mu \mathrm{m}$ Au wire bonded to Ag pad

\begin{tabular}{l|c|c|c|c}
\hline \multirow{2}{*}{ Pad formation } & \multirow{2}{*}{ Thickness, $\mu \mathrm{m}$} & \multicolumn{3}{|c}{ Strength, cN } \\
\cline { 3 - 5 } & & Max. & Min. & Avg \\
\hline \multirow{2}{*}{ Laser sintering } & 0.20 & 10.3 & 6.0 & 8.2 \\
\cline { 2 - 5 } & $3.0-3.2$ & 10.5 & 7.0 & 8.6 \\
\hline \multirow{2}{*}{ Electroplating } & 0.20 & 9.9 & 7.0 & 8.4 \\
\cline { 2 - 5 } & 2.0 & 10.1 & 7.6 & 8.5 \\
\hline
\end{tabular}

(100-110 samples for laser sintering, 50 samples for electroplating)

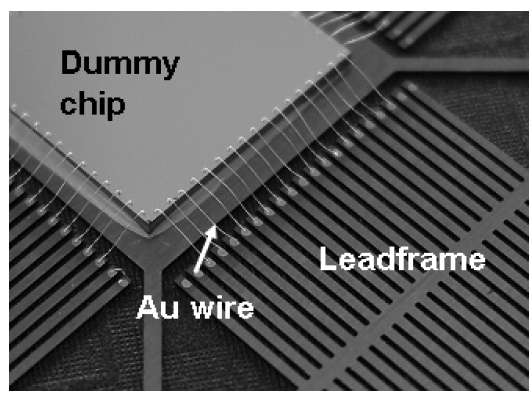

Fig. 24 Chip to substrate wire bonding with lasersintered pads

ここで, 膜厚約 $0.20 \mu \mathrm{m}$ の焼結膜では, ボンディング数 110 に対し，ワイヤの接合割合は約 $95 \%$ であるが，約 $50 \%$ 以上の割合でウェッジ (2nd) ボンド側で破断し，接合割 合やその強度がばらついた。一方で膜厚約 $3.0 \mu \mathrm{m}$ の焼結膜 では, ボンディング数 100 前後に対し, ワイヤの接合割合 は約 $100 \%$ で, ウェッジ (2nd) ボンド側での破断もなく, 非常に良好な結果が得られている。このように, 膜厚増加 によるばらつき改善効果も加わり, データの再現性に関し ても, めっき膜とほぼ同等の值が得られた。

現在, 銅LFのダイパッドに, アルミニウムを蒸着した ダミーチップを搭載し，そのチップとリード先端とのWB にも成功している（Fig. 24参照）。今後は，本技術の実用 化に向け, 銅 LF上の機能性膜のさらなる信頼性獲得が課 題となる。

\section{5. 結 論}

本研究では，金属ナノ粒子ペーストのインクジェット印 刷技術とレーザ焼結技術を組み合わせた省資源・低環境負 荷型のプリンテッドエレクトロニクス製造に関し，とくに 微細配線やワイヤボンディング用パッド形成に適用するた めの実用化検証を進めてきた。その過程で, 平均粒径 $5 \mathrm{~nm}$ の銀ナノ粒子ペーストを用いて, バルク構造に近い 機能性膜を得るためには，レーザ焼結前に溶媒除去を目的 とした加熱処理が必要であること，ペーストに対して吸光 度の低い連続波近赤外レーザ光を照射して基板側から焼結 させること, 高分子保護膜を離脱させるための加熱時酸素 を必要としないこと，など金属ナノ粒子ペーストのレーザ 焼結に特有な知見が得られた。

銅基板や PI 基板上への微細配線形成では，基板との高 い密着強度を示す導電膜の形成が可能であることを確認し た。
一方，銅基板や銅 LF上へのWB用パッド形成に関して は，下記に挙げる結果が得られた。

（1）本手法を用い，銅基板または銅 LF上への銀焼結膜 形成が可能である。

（2）シングルステップ印刷時に得られる最大の膜厚は, 銅基板および銅 LF上で約 $0.20 \mu \mathrm{m}$ である。

(3) マルチステップ印刷法の確立により, 銅LF上へ膜 厚 $2 \sim 3 \mu \mathrm{m}$ の十分に厚く, 平坦な焼結膜を形成することが できる。

（4）膜厚 $2 \sim 3 \mu \mathrm{m}$ の焼結膜にボンディングしたワイヤ のプル強度や再現性は, めっき膜とほぼ同等である。

しかしながら, 現状では, 実用化に必要な膜厚 $7 \mu \mathrm{m} に$ 対して十分な膜厚が得られないことから，今後は，微細配 線形成条件などの最適化が必要である。一方, WB用パッ ドとしてさらなる信頼性獲得のほか, IJ印刷とレーザ焼結 を組み合わせたレーザアシスト焼結装置の設計開発や，分 子保護膜付き金属ナノ粒子の焼結メカニズムの解明を進め ていく。

\section{謝 辞}

機能性膜の分析・評価にご協力いただいた茨城県工業技 術センター 浅野俊之氏に感謝の意を表する。本研究は, 科学技術振興機構 JSTイノベーションサテライト茨城平成 18 年度採択課題（育成研究）, ならびに平成 21 年度JST研 究成果最適展開支援事業 (A-STEP) 「フィージビリティス タディ（起業検証）」の支援の下に実施された。

(2011.7.23-受理)

\section{文献}

1) R. K. Ulrich and W. D. Brown: "Advanced Electronic Packaging," 2nd Ed., Wiley-Interscience, pp. 112-127, 2006

2) Z. Radivojevic, K. Andersson, K. Hashizume, M. Heino, M. Mantysalo, P. Mansikkamaki, Y. Matsuba, and N. Terada: "Optimised Curing of Silver Ink Jet Based Printed Traces," Nice, Côte d'Azur, France, 27-29 September 2006, TIMA Editions/ THERMINIC, pp. 163-168, 2006

3) N. R. Bieri, J. Chung, D. Poulikakos, and C. P. Grigoropoulos: "An Experimental Investigation of Microresistor Laser Printing with Gold Nanoparticle-Laden Inks," Appl. Phys. A, Vol. 80, pp. 1485-1495, 2005

4) P. Laakso, S. Ruotsalainen, E. Halonen, M. Mäntysalo, and A. Kemppainen: "Sintering of Printed Nanoparticle Structures using Laser Treatment," ICALEO 2009, Paper \#N205, 2009

5）遠藤聡人, 明渡 純: “レーザー援用インクジェット技術 の開発一高スループットとファイン化の両立を目指した配 線技術一, ”産総研学術ジャーナル シンセシオロジー, Vol. 4, No. 1, pp. 1-10, 2011

6) K. Maekawa, M. Mita, K. Yamasaki, T. Niizeki, Y. Matsuba, N. 
Terada, and H. Saito: "Packaging of Electronic Modules through Completely Dry Process," The 58th Electronic Components and Technology Conference (ECTC 2008), Lake Buena Vista, Florida, USA, May 27-30, pp. 950-955, 2008

7) K. Maekawa, K. Yamasaki, T. Niizeki, M. Mita, Y. Matsuba, N. Terada, and H. Saito: "Influence of Wavelength on Laser Sintering Characteristics of Ag Nanoparticles," The 59th Electronic Components and Technology Conference (ECTC 2009), San Diego, California, USA, May 26-29, pp. 15791584,2009

8) T. Niizeki, K. Maekawa, M. Mita, K. Yamasaki, Y. Matsuba, N. Terada, and H. Saito: "Laser Sintering of Ag Nanopaste Film and Its Application to Bond-Pad Formation," The 58th Electronic Components and Technology Conference (ECTC 2008), Lake Buena Vista, Florida, USA, May 27-30, pp. 17451750,2008

9) K. Maekawa, K. Yamasaki, T. Niizeki, M. Mita, Y. Matsuba, N. Terada, and H. Saito: "High-Speed Laser Plating for WireBonding Pad Formation, Transactions of The Japan Institute of Electronics Packaging," Vol. 3, No. 1, pp. 7-13, 2010

10) K. Maekawa, K. Yamasaki, T. Niizeki, M. Mita, Y. Matsuba, N. Terada, and H. Saito: "High-Speed Laser Plating on Cu Leadframe Using Ag Nanoparticles," 60th Electronic Components and Technology Conference (ECTC 2010), Paris Las Vegas, Las Vegas, NV USA, June 1-4, pp. 440-446, 2010

11) T. Kajiya, D. Kaneko, and M. Doi: "Dynamical Visualization of "Coffee Stain Phenomenon" in Droplets of Polymer Solution via Fluorescent Microscopy," Langmuir, Nov. Vol. 4, No. 24(21), pp. 12369-12374, 2008

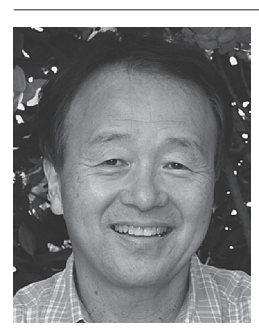

著者紹介

前川克廣（まえかわ かつひろ）

1979年, 東京工業大学大学院博士課程機械物理 工学専攻修了, 工学博士。現在、茨城大学工学部 機械工学科教授。

レーザ応用マイクロ構造創製の研究に従事。日本 機械学会, 精密工学会、応用物理学会, エレクト ロニクス実装学会会員。

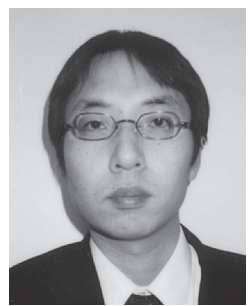

山崎和彦（やまさき かずひこ）

2003 年, 徳島大学大学院工学研究科博士後期課 程修了, 博士 (工学)。現在, 茨城大学工学部機 械工学科講師。

レーザプロセシング，微細加工の研究に従事。日 本機械学会, 精密工学会, 応用物理学会会員。

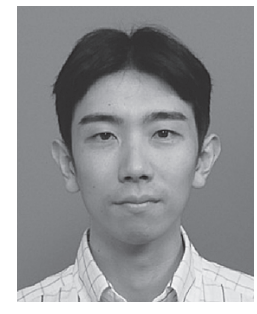

新関智丈（にいぜき ともたけ）

2004 年, 茨城大学大学院理工学研究科博士後期 課程環境機能科学専攻単位取得退学。茨城県工業 技術センター, 科学技術振興機構, 茨城大学にお いて研究員を務め，現在，（株）アート科学で研 究開発を担当。

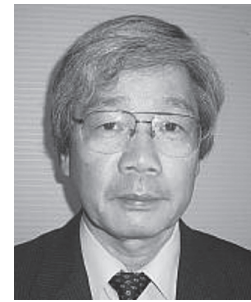

御田 護（みたまもる）

（株）M\& M研究所代表取締役。

元日立電線 (株) 半導体材料事業本部企画開発部

長，専門分野は半導体実装プロセス，金属表面技

術，技術士 (金属部門), 博士 (工学)。「高速 レーザめっき法」を提唱し，事業化に向け奮闘 中。

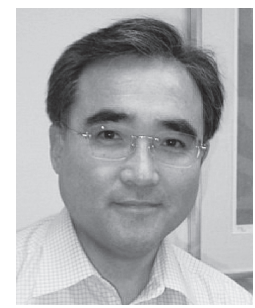

松葉頼重（まつば よりしげ）

1979年, 岡山大学大学院工学研究科修了。現在, ハリマ化成（株）取締役筑波研究所所長。 2000 年，金属ナノ粒子による導電性インク「ナ ノペースト」を開発。インクジェットとの組合せ による「リキッドワイヤリング工法」を提唱し， 実用化に向け奮闘中。

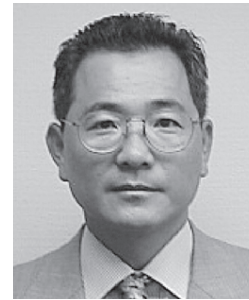

寺田信人（てらだのぶと）

1983年, 名古屋工業大学工学部卒業。現在, 八 リマ化成（株）筑波研究所研究グループ長。 中央研究所にて塗料用樹脂の開発に従事後, 1988 年から筑波研究所にてアンダーフィル材等を商品 化。その後,ナノペースト, 導電性ペーストの開 発を担当。

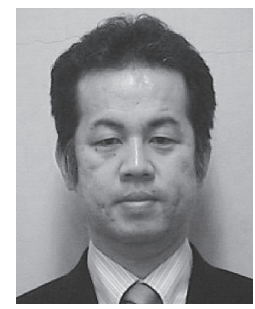

齊藤 寛（さいとう ひろし）

2001 年, 筑波大学大学院化学研究科博士課程修 了。現在，ハリマ化成（株）筑波研究所研究員。 入社以来，金属ナノ材料の開発抢よびインク ジェット印刷を中心にプリンテッドエレクトロニ クスへの材料応用の研究に従事。 